PROBLEMS

OF EDUCATION

IN THE $21^{\text {st }}$ CENTURY

Volume 48,2012

52

SELECTED FACTORS AFFECTING GIRLS' PARTICIPATION IN PRIMARY SCHOOL EDUCATION IN KENYA

\author{
Benjamin C. Kipkulei,Micah C. Chepchieng \\ Egerton University, Egerton, Kenya \\ E-mail: kipkuleibenjamin@yahoo.com, mchemobo@yahoo.com
}

Mary J. Chepchieng

Kabarak University, Kabarak, Kenya

E-mail: mary.chemobo@yahoo.com

Lydia M. Boitt

Egerton University, Kenya

E-mail: lydiamonny@yahoo.com

\begin{abstract}
The girl child participation in primary school level of education has become a real concern in all nations of the World particularly in the developing countries of the Sub-Saharan Africa, Kenya included. Girl child education worldwide provides benefits to the family and the society at large thus factors affecting it should be addressed for the sake of human and societal development. The objective of the study was to establish the factors affecting girls' participation in primary schools in Kenya. Specifically, the study investigated the effect socio-economic, socio-cultural and school-based factors have on a girl-child's participation in primary school education in Kenya. In some parts of Kenya, there is low girls' participation in primary school education thus the interest in establishing the factors that may be contributing to this problem. This was considered crucial as Kenya strives to achieve basic Education for All by 2015. The study employed a survey design. 210 girls drawn from primary classes 6, 7 and 8 participated in the study. The simple random technique was used in the selection of the sample. A questionnaire was used to collect data that were analyzed by use of descriptive statistics (frequencies and percentages). The findings of the study revealed that socio-economic, socio-cultural and school related factors affect girls' participation in primary schools in Kenya. In effect, unless these factors are expeditiously addressed, primary school girls will continue to be disadvantaged in the Kenya's school system. This will frustrate the world's efforts in attaining basic education for all by 2015. The study therefore recommended that the Ministry of Education in Kenya should create awareness to all education stakeholders on the importance of girl child education in the country. It was also recommended that a large scale study involving sub-Saharan Africa developing nations experiencing low girls' participation in education be carried out to falsify or corroborate the findings.
\end{abstract}

Key words: education, factors, girls' participation, socio-economic, socio-cultural, school-based.

\title{
Introduction
}

Since the World Declaration of Education for All (EFA) in 1990, many developing countries, Kenya included have been making strides to realize the universalization of primary education as well as to minimize illiteracy rates among their populations. Particularly, greater efforts have been made by governments worldwide to improve the education of women. This 
is due to the research studies that show that two-thirds of those who cannot read and write are women and that $60 \%$ of children not in school are girls (World Bank, 1995 cited in Adetunde $\mid \begin{aligned} & \text { PROBLEMS } \\ & \text { OF EDUCATION } \\ & \text { IN THE 21 } 1^{\text {st }} \text { CENTURY } \\ & \text { Volume 48, } 2012\end{aligned}$ \& Akampae, 2008). If this trend is not checked, imbalances in enrollment of girls in primary schools will affect their enrollment in secondary schools and other levels of education. As a result, widening gaps in earnings between men and women will continue to be witnessed in the society. Besides, educational status of women in any nation has been known to correlate with its level of development. According to Adebola, Anyachebelu and Madu (2012), the higher the level of girls' education status, the more developed a nation is. However, even with this knowledge about women education, inequality in female participation in education is still glaring despite commitments by various governments to the attainment of the Millennium Development goal of $8^{\text {th }}$ of September, 2000 that by the year 2015 all children worldwide of both genders would have equal access to all levels of education. This witnessed inequality is attributed to a myriad of factors. The authors of the paper therefore focused on how some selected factors affect girl child participation in primary schools in Kenya. Specifically, socio-economic, socio-cultural and school-based factors were investigated. In the society where the study was situated, the education of boys is seen as more important than that of girls. But as to how such a sociocultural factor and other related factors affect girls participation in education is of paramount importance in order to come up with effective interventions that will facilitate achievement of gender parity in education.

\section{Problem of the Research}

Despite the critical role female education plays in the society, Kenya still witnesses gender disparity in all levels of education, 49 years after independence. The affected level is the primary where the enrollment of girls is still below 50\%. The Kenyan government has put in efforts to address this situation that includes introduction of Free Primary Education from class one to eight. But, even with this, gender disparities are still observed in performance, access, retention, transition in primary education (Ministry of Education, 2007). Consequently, there is need to investigate the factors that militate against girl participation in primary school education in Kenya.

\section{Research Focus}

In Africa where the current study was done, girls' primary school enrolment accounts for only $57 \%$ of the school-age population as compared with $75 \%$ to boys, (Adetunde \& Akampae, 2008). This gender disparity in education seems to cut across continents. Research studies for instance, UNICEF (2005) as cited in Arai and Tabata (2006) show that South Asia was not to reach gender parity by the end of 2005, and unlikely to achieve Universal Primary Education by 2015. In Britain, research by Skelton, Francis and Valkanova (2007) found out that education continues to be experienced along gendered lines despite long term efforts to equalize boys and girls education.

Several studies have shown that female education worldwide provides benefits to the family and the society at large (Adebola, Anyachebelu \& Madu, 2012; Adetunde \& Akampae, 2008; Mwangi, Mungai, \& Chiuri, 2001). Hence, there is a continuous need to study the factors that negatively affect girls' participation in education so as to make education accessible to them to enable them contribute meaningfully to communities and nations' development. 
PROBLEMS

OF EDUCATION

IN THE $21^{\text {st }}$ CENTURY

Volume 48, 2012

\section{Methodology of Research}

\section{General Background of the Research}

The design adopted for the study was a survey. The study was carried out in the Barwessa Division of Baringo District, Kenya. The division is situated in an Arid and Semi-Arid (ASAL) area and it is one of the most affected areas in Kenya in relation to girls' participation in primary school education.

\section{Sample of the Research}

The study targeted a population of 882 school girls enrolled in classes 6,7 and 8 drawn from 10 primary schools. These classes were chosen because pupils at these levels of primary education in the Kenyan education system are able to read, understand and respond to questionnaire items with little difficulty as compared to those at lower grades. In Kenya, the primary level of education ends at class 8 . Normally, the class 8 pupils are not involved particularly if a study is a carried out when they are busy preparing for their national examination. However, this study was carried out at a time when their participation was not detrimental to their examination preparation. Out of the targeted population, a sample size of 210 girls participated in the study. The simple random technique was used to select 21 girls from each school ( 7 girls per class).

\section{Instrument and Procedures}

A questionnaire was used in the collection of data from the respondents. The questionnaire had three sections, A, B and C which addressed the socioeconomic, socio-cultural and school based factors affecting girls' participation respectively. The questionnaire was structured on a five point Likert scale of Strongly Agree (SA), Agree (A), Uncertain (U), Disagree (D) and Strongly Disagree (SD). The questionnaire was validated by two research experts in educational psychology. Through the validation, experts were asked to check on the clarity of instructions to respondents, wordings of items, and appropriateness and adequacy of the items in addressing the variables of interest. The experts' recommendations on the instrument made the researchers to modify some items of the instrument. Further, a pilot study was done in three primary schools to get the perspectives of the respondents on the items and also to establish the reliability of the instrument. The reliability was determined using the Cronbach's Alpha method. The coefficient alpha of the instrument was 0.89 . This value was 0.19 points above the recommended threshold of 0.7 (Kathuri \& Pals, 1993; Fraenkel \& Wallen, 2000). As such, the instrument was considered highly reliable for use. From the group of the respondents, at least $96.5 \%$ of them responded to the items.

\section{Data Analysis}

The selected factors that affect girls' participation in primary school education were grouped into various categories: socioeconomic, socio-cultural and school based factors. To establish the extent to which the factors affect girl child participation in education, descriptive statistics were applied. Consequently, frequency and percentage tables were generated. 


\section{Results of Research}

\section{Socioeconomic Factors Affecting Girls'Participation in Primary School Education}

Socioeconomic factors considered in the study were: Parental income, education and occupation. The respondents were asked to give a response about the factor(s) they perceived to have affected their participation in primary education by indicating their levels of agreement as per the Likert scale's levels of intensities: Strongly agree, agree, uncertain, disagree and strongly disagree. The level indicated in this study showed the extent to which the factor responded to has affected the pupils' participation in primary school education.

Results show that $74 \%$ of the girls strongly agreed that income of parents affect their participation in primary school education whereas $21.5 \%$ agreed. Thus, cumulatively $95.5 \%$ of the girls are in agreement that indeed parental income is a factor that has affected them. High parental income enables parents to meet the basic needs, regularly buy school uniforms, food, learning materials and sanitary towels for their daughters. However, in a society such as the one the study was carried out where the education of boys is seen as more important than that of girls, the needs of the girls may not be considered by their parents hence make them to miss or completely drop out of school. In Kenya, the Free Primary Education that was introduced in 2002 only caters for tuition and basic learning materials and not uniforms, food and sanitary towels among other needs for girls. This may be the reason why despite the introduction of Free Primary Education, gender disparities are still observed in performance, access, retention and transition particularly in Arid and Semi-Arid areas of the country.

On Parental education, results reveal that $35 \%$ and $56.5 \%$ strongly agreed and agreed respectively that parental education affects girls' participation in education, while only $2.5 \%$ and $5 \%$ were undecided and disagreed respectively that parental education affects girls' participation in education. Therefore, on the overall, majority $(91.5 \%)$ of the girls agreed that parental level of education has militated against their participation in education. The results of this research has proved that there is a close coherence between the meaning of education to parents and their children's participation in education, that is if education is regarded as a value in the family, there are high chances that children will participate in education. Consequently, parents and other family members are role models for their children or siblings in education matters.

Observation on the association between parental occupation and girls' education clearly shows that $82.5 \%$ of the girls positively agreed that a parent's occupation affects girls' participation in education. Only $13 \%$ and $11 \%$ of the respondents were undecided and disagreed respectively with this view. Generally, parents with higher education tend to secure gainful occupations and hence enhanced incomes which lead to acquisition of better resources, selfesteem and more increased girls' motivation to pursue education. It can therefore be concluded that parental income, education and occupation as indicators of socioeconomic status greatly affect girls' participation in education. However, out of these three factors, parental income and education are the leading factors.

Table 1. Socioeconomic Factors Affecting Girls' Participation in Primary Education.

\begin{tabular}{|c|c|c|c|c|c|c|c|c|c|c|}
\hline \multirow[b]{2}{*}{ Factors } & \multicolumn{10}{|c|}{ Girls' Responses } \\
\hline & $\begin{array}{c}\text { SA } \\
f\end{array}$ & $\%$ & $\begin{array}{l}A \\
f\end{array}$ & $\%$ & $U_{f}$ & $\%$ & $\begin{array}{l}D \\
f\end{array}$ & $\%$ & $\begin{array}{c}S D \\
f\end{array}$ & $\%$ \\
\hline Parental income & 148 & 74 & 43 & 21.5 & 3 & 1.5 & 11 & 5.5 & 0 & 0 \\
\hline Parental level of education & 70 & 35 & 113 & 56.5 & 5 & 2.5 & 10 & 5 & 2 & 1 \\
\hline Parental occupation & 73 & 36.5 & 92 & 46 & 13 & 6.5 & 22 & 11 & 0 & 0 \\
\hline
\end{tabular}


PROBLEMS

OF EDUCATION

IN THE $21^{\text {st }}$ CENTURY

Volume 48, 2012

56

\section{Socio-cultural Factors Affecting Girls'Participation in Primary School Education}

The socio-cultural factors examined were Female Genital Mutilation, Early Marriage and Parental attitudes towards the girl-child education. The respondents were required to respond to each item by indicating strongly agree, agree, undecided, disagree or strongly disagree as earlier explained in Table 1.

The results show that socio-cultural affects of girl-child participation in primary school education in Kenya. 92\% of the girls positively agreed that Female Genital Mutilation (FGM), as a socio-cultural factor has affected their participation in primary school education. FGM has been known to have a wide range of psychological and psychosomatic disorders. According to Kiptiony (2008), girls may experience disturbances in sleep patterns, mood and cognition. Abor (2006) in a study done in Ghana revealed that FGM affects both the physical and psychological well-being of a girl-child due the female genital deformation and mental torture resulting from the pain undergone. With such effects, a girl-child may lack the requisite attention and concentration for good academic performance. Consequently, such a child may fail in school work, experience low self-esteem and eventually drop out of school. Greater effect is observed in parental attitude towards girls where $98 \%$ of the girls positively agreed that it is critical factor. In a study carried out in Pakistan, gender disparity in education is attributed to a large extent to the parent's attitude against girls (Arai \& Tabata, 2006). In this country, parents do not give permission to the girls to go to school. It seems then that this socio-cultural factor may be cutting across many regions of the world.

Early marriage is another socio-cultural factor that $91 \%$ of the girls identified as affecting their participation in primary school education. Early marriage denies a girl-child the opportunity to attend school. In some rural Arid and Semi-arid areas of Kenya, parents still arrange some marriages for their children. When this is done, it is usual for the girl-child as young as 12 years to quit school thus the level of education and marrying age parents expect of their daughters is coherent. On the teenage pregnancies, $93.5 \%$ of the girls positively agreed that it is a factor militating against their education. In Kenya, girls who become pregnant usually face a lot of ridicule from their fellow pupils to the extent that it would be difficult for them to return to school after giving birth. Though the government and Non-Governmental organizations have been very supportive to such girls and even give them a leeway to join schools of their choice to recover from the pregnancy stigma, this has born little fruit, an indication that it is a serious stigma that require psychological interventions.

It is evident from the study that out of the four socio-cultural factors examined; parental attitude against girls is the most recognized factor. This could explain the scenario where in spite of the commitment on the side of the government to decrease financial burden of parents through the provision of Free Primary Education, acceptable levels of school enrolment and gender parity in primary education does not seem to be forthcoming.

Table 2. Socio-cultural Factors Affecting Girls' Participation in Primary Education.

\begin{tabular}{|l|c|c|c|c|c|c|c|c|c|c|}
\hline \multirow{3}{*}{ Factors } & \multicolumn{10}{|c|}{ Girls' Responses } \\
\cline { 2 - 13 } & $\begin{array}{c}\text { SA } \\
\mathrm{f}\end{array}$ & $\%$ & $\begin{array}{c}\mathrm{A} \\
\mathrm{f}\end{array}$ & $\%$ & $\begin{array}{c}\mathrm{U} \\
\mathrm{f}\end{array}$ & $\%$ & $\begin{array}{c}\mathrm{D} \\
\mathrm{f}\end{array}$ & $\begin{array}{c}\text { SD } \\
\mathrm{f}\end{array}$ & \\
\hline Female Genital Mutilation & 128 & 64 & 56 & 28 & 7 & 3.5 & 7 & 3.5 & 0 & 0 \\
\hline Parental attitude towards Girls & 136 & 68 & 60 & 30 & 4 & 2 & 1 & 0.5 & 0 & 0 \\
\hline Early Marriage & 110 & 55 & 72 & 36 & 11 & 5.5 & 5 & 2.5 & 2 & 1 \\
\hline Teenage Pregnancies & 37 & 18.5 & 150 & 75 & 8 & 4 & 3 & 1.5 & 0 & 0 \\
\hline
\end{tabular}


Benjamin C. KIPKULEI, Micah C. CHEPCHIENG, Mary J. CHEPCHIENG, Lydia M. BOITT. Selected Factors Affecting Girls' Participation in Primary School Education in Kenya

\section{School-based Factors Affecting Girls'Participation in Education}

The school-based factors the pupils responded to were Learning materials (books and stationery), Teacher-pupil interaction and Adequacy of sitting furniture. The respondents were required to respond to each item by indicating strongly agree, agree, undecided, disagree or strongly disagree as earlier explained in Tables 1 and 2 .

Table 3. School-based Factors Affecting Girls' Participation in Primary Education.

\begin{tabular}{|c|c|c|c|c|c|c|c|c|c|c|}
\hline \multirow[b]{2}{*}{ Factors } & \multicolumn{10}{|c|}{ Girls' Responses } \\
\hline & $\begin{array}{c}\text { SA } \\
f\end{array}$ & $\%$ & $\begin{array}{l}A \\
f\end{array}$ & $\%$ & $\mathrm{U}$ & $\%$ & $\begin{array}{l}D \\
f\end{array}$ & $\%$ & $\begin{array}{c}\text { SD } \\
f\end{array}$ & $\%$ \\
\hline Learning materials & $\frac{1}{128}$ & $\begin{array}{l}10 \\
64\end{array}$ & $\frac{1}{56}$ & 28 & $\frac{1}{7}$ & 3.5 & $\frac{1}{7}$ & 3.5 & $\frac{1}{-}$ & 10 \\
\hline Teacher-pupil interaction & 136 & 68 & 60 & 30 & 4 & 2 & 1 & 0.5 & - & - \\
\hline Adequacy of sitting furniture for girls & 110 & 55 & 72 & 36 & 11 & 5.5 & 5 & 2.5 & 2 & 1 \\
\hline
\end{tabular}

It is evident from the results shown in Table 3 that cumulatively, $92 \%$ of the respondents positively agreed to the learning materials to be a school-based factor contributing to their participation in education. In Kenya, the Free Primary Education provides basic text books, teaching aids and stationery, meaning that the girls still depend highly on their parents or guardians to provide class texts and stationery.

On teacher-pupil interaction, it is observed that $98 \%$ of the girls identified this as a factor. This implies that each individual teacher creates a learning climate either through formal or informal interactions with pupils. Pupils are human first and learners second. Thus, the school is not only an educational institution for teachers to enhance pupils' learning but also an interactive community of human beings.

Finally, the adequacy of sitting furniture was explored. Results indicate that $91 \%$ of the pupils both strongly agreed and agreed that this school factor is a contributor to their participation in education. In rural parts of Kenya, particularly in Arid and Semi-arid areas, school infrastructure is not good including pupil seats. Many pupils both boys and girls share a seat/bench and some, particularly girls may be uncomfortable squeezing on one seat. In effect, some especially the mature ones may opt out of school. The study result clearly shows that availability of resources enhances or promotes girls' participation in education, while inadequacy of these resources adversely affects their participation.

\section{Discussion}

Previous research indicates that socioeconomic factors play a critical role in children's education. For instance, Brock and Camish (1997) show that the economic factor, especially in terms of grinding poverty and hunger adversely affect female participation in education, especially in rural areas. Literature further indicate that girls from better off homes, who live in urban areas are more likely to enroll and remain in school for longer period than those from poorer home and rural areas (World Bank, 1995). Moreover, in many countries where parents are required to pay school fees, buy school furniture, textbooks and uniforms; an economic commitment that poorer or average parents cannot meet, such parents may choose not to send girls to school (Kabira \& Masinjila, 1997; World Bank, 1995). According to World Bank (1995) in a study carried out in Zimbabwe, at the onset of menstruation, girls who have no underwear or sanitary protection remain at home while menstruating and this undermines their confidence 
PROBLEMS

OF EDUCATION

IN THE $21^{\text {st }}$ CENTURY

Volume 48, 2012

58 (Guthrie, 1978; Lietz, 1996; OECD, 2001, 2002; Purves, 1973; Taube, 1988) all cited in Geske and Ozola (2008) show parents' level of education and socioeconomic position of the family play an important role in the learning achievements of their children. Learning achievements of children is critical in determining whether they will remain in school or not. In this study, results reveal that out of the three socioeconomic factors i.e parental income, parental level of education and parental occupation; parental income and level of education emerged as the critical factors influencing girl-child participation in education in Kenya.

The results of the research also show that socio-cultural factors affect girls' participation in education. The results corroborate other researches that found early marriage can deny a girl the opportunity of going to school (Adebola, Anyachebelu \& Madu, 2012; Arai \& Tabata, 2006). Usually, girls who drop out of school to get married are difficult to return to school after marriage. This could be attributed to what Udoh (2001) as cited in Adebola, Anyachebelu and Madu, (2012) noted that early responsibility of motherhood thrust on a girl would sentence her to life of hopelessness. Studies on Female Genital Mutilation, show that its effects are both physical and psychological (Delano, 1999 cited in Adebola, Anyachebelu \& Madu, 2012; Abor, 2006; Kiptiony, 2008). For example heavy bleeding and frequency in passing of urine which are some of the aftermaths of FGM results in pain, infections and low self-esteem which are potential in affecting girls' classroom attention and concentration consequently affecting their learning achievements.

Studies have revealed that parental attitude towards a son and a daughter is a fundamental cultural factor. Particularly, the attitude of fathers has been established to be a key factor in encouraging or restricting the schooling of their daughters (Arai \& Tabata, 2006; Brock \& Camish, 1997). These findings are in agreement with the present study result where $98 \%$ of the girls identified parental attitude against them to be a paramount factor in their participation in schooling.

In many countries, some pupils are responsible for covering some of their educational costs particularly in rural poor families. For young girls in upper primary school, the responsibility for covering their educational costs often leads to sexual relationships with older men who are willing to exchange sexual favours with financial support. Such relationships carry the risk of teenage pregnancy which deters their schooling (Chepchieng \& Kiboss, 2004; World Bank, 1995).

The interactions which teachers have with pupils are of great importance to pupils' schooling. Studies have proved that interactions with peers and teachers in school or college are important social factors that could impact the psychological well-being of a child particularly those approaching or already in adolescence (Feldman \& Newcomb, 1969 as cited in Perez, 2012). The psychological well-being as Perez (2012) noted could lead to adaptive human functioning and positive life experiences. In effect, a child with good psychological well-being will persistently pursue education despite challenging life experiences. In this study, the girls identified teacher-pupil interactions as the major school-based factor affecting their participation in education.

\section{Conclusions}

The study established parental income as a leading socioeconomic factor affecting girls' education. This is closely followed by parental education; meaning there is a close coherence between the meaning of education to parents and their children's participation in education. Thus, if education is regarded as a value in the family, there are high chances that children will participate in education. 
Also, the study has revealed that girls are affected by some socio-cultural factors. Specifically,

Parental attitude towards the girls has been shown to adversely affect their participation in education. On the school-based factors, interactions of teachers with pupils, either inside the classroom or outside the classroom, exert a great deal of impact on pupils' education.

Since the education of female is paramount to the development of a nation, a girl faced with socioeconomic, socio-cultural and school challenges will not progress in schooling hence cannot do much in the development of a nation at the community, regional and national levels.

\section{Recommendations}

Considering the findings of the study, governments and Non-governmental organizations need to step up their efforts to eliminate the socio-cultural practices that disadvantage the girlchild in order to achieve gender parity in education. The Kenyan government in particular, should continue offering the Free Primary Education and even enhance it more to decrease the financial burdens of poor parents. In addition, the Ministry of Education in Kenya should create awareness to all education stakeholders on the importance of girl child education in the country. Finally, a large scale study involving sub-Saharan Africa developing nations experiencing low girls' participation in education to be carried out to falsify or corroborate the findings.

\section{References}

Abor, A. P. (2006). Female Genital Mutilation: psychological and reproductive health Consequences: The case of Kayoro traditional area in Ghana. Journal of Gender and Behaviour, 4 (1), 659-684

Adebola, H., Anyachebelu, F. E., \& Madu, C. O. (2012). Towards empowerment of the Nigerian girl-child, the socio-cultural diagnosis. Journal of Educational and Social Research, 2 (3), 2934.doi:10.5901/jesr.2012.v2n3p29

Adetunde, I. A., \& Akampae, P. A. (2008). Factors affecting the standard of female education: A case study of senior secondary schools in the Kassena-Nankana District. Journal of Social Sciences, 4 (4), 338-342. doi:10.384/jssp.2008.338.342

Arai, K., \& Tabata, Y. (2006). Socio-cultural factors affecting girls' limited access to school education in North West Frontier Province of Pakistan. November APERA Conference, Hong Kong (2830). Retrieved on October 16, 2012 from, http://edisdat.ied.edu.hk/pubarch/b15907314/full_ paper/1394178079.pdf

Brock, C., \& Camish, N. (1997). Factors affecting female participation in education in seven developing countries. Education Research Paper No.9, 1993 ( $2^{\text {nd }}$ Ed.). Oxford: Department for International Development.

Chepchieng, M. C., \& Kiboss, J. K. (2004). Influence of family socio-economic status and gender on students' academic performance. Journal of Education and Human Resource, 2 (2), 50-62.

Delano, G. E. (1999). Mother and child health. A handbook for traditional birth attendants and other health workers. Association for Reproductive and \& Family Health, Ibadan Ikolaba.

Adebola, H., Anyachebelu, F. E., \& Madu, C. O. (2012). Towards empowerment of the Nigerian girlchild, the socio-cultural diagnosis. Journal of Educational and Social Research, 2 (3), 29-34. doi:10.5901/jesr.2012.v2n3p29.

Feldman, K. A., \& Newcomb, T. M. (1969). The impact of college on students. In: Perez, J.A. (2012). Gender difference in psychological well-being among Filipino college student samples. International Journal of Humanities and Social Science, 2 (13), 84-93. Retrieved on October 20, 2012 from http://www.ijhssnet.com/jounals/vol_2_No_July_2012/8.pdf.

Fraenkel, J. R., \& Wallen, N. E. (2000). How to design and Evaluate Research in Education. San Francisco: McGraw Hill.

Geske, A., \& Ozola, A. (2008). Factors influencing reading and literacy at the primary school Level. Problems of Education in the 21 $1^{\text {st }}$ Century, 6, 71-77. 
PROBLEMS

OF EDUCATION

IN THE $21^{\text {st }}$ CENTURY

Volume 48,2012

60 Guthrie, J. T. (1978). Research views: comics. In: Geske, A., \& Ozola, A. (2008). Factors Influencing Reading and Literacy at the Primary School Level. Problems of Education in the $21^{\text {st }}$ Century, 6 , 71-77.

Kabira, W. M., \& Masinjila, M. (1997, July). ABC of Gender analysis. Nairobi: Fawe news, 23 (1), 13-14.

Kathuri, J. N., \& Pals, D. A. (1993). An Introduction To Educational Research. Njoro: Egerton University.

Kiptiony, G. J. (2008). A Knifeless Rite: Influence of Selceted Characteristics on the Marakwet of Kenya's Perceptions of the Counselling-Based Alternative Rite of passage and Levels of Awarenes on Effects of FGM. Unpublished PhD thesis, Egerton University, Kenya.

Leitz, P. (1996). Changes in reading comprehension across cultures and over time. In: Geske, A., \& Ozola, A. (2008). Factors Influencing Reading and Literacy at the Primary School Level. Problems of Education in the 21 $1^{\text {st }}$ Century, 6, 71-77.

Mwangi, G., Mungai, V. W., \& Chiuri, L. W. (2001). Using pre-schools to reduce gender imbalance among science professionals in Sub-Saharan Africa critical issues. Journal of Education and Human Resources, 1 (1), 1-13.

Ministry of Education (2007). Gender Policy in Education in Kenya. Nairobi. Government Printers.

Organisation for Economic Co-operation and Development. (2001). Knowledge and skills for life. First results from PISA 2000. In: Geske, A \& Ozola, A. (2008). Factors influencing reading and literacy at the primary school Level. Problems of Education in the $21^{\text {st }}$ Century, 6, 71-77.

Organisation for Economic Co-operation and Development. (2002). Reading for change. Performance and engagement across countries. In: Geske, A., \& Ozola, A. (2008). Factors influencing reading and literacy at the primary school Level. Problems of Education in the 21 $1^{\text {st }}$ Century, 6, 71-77.

Perez, J. A. (2012). Gender difference in psychological well-being among Filipino college student samples. International Journal of Humanities and Social Science, 2 (13), 84-93. Retrieved on October 20, 2012 from http://www.ijhssnet.com/jounals/vol_2_No_July_2012/8.pdf.

Purve, A. (1973). Literature education in ten countries. In: Geske, A \& Ozola, A. (2008). Factors Influencing Reading and Literacy at the Primary School Level. Journal of Problems of Education in the $21^{\text {st }}$ Century, 6, 71-77.

Skelton, C., Francis, B., \& Valkanova, Y. (2007). Breaking down the stereotypes: Gender and achievement in schools. EOC Working Paper series No.9. England, EOC. Retrieved from http://archive. excellencegateway.org.uk/page.aspx?o=282759

Taube, K. (1988). Reading acquisition and self-concept (dissertation). In: Geske, A., \& Ozola, A. (2008). Factors Influencing Reading and Literacy at the Primary School Level. Journal of Problems of Education in the 21 ${ }^{\text {st }}$ Century, 6, 71-77.

Udoh, C. O. (2001). The tragedy of the girl-child. In: Adebola, H., Anyachebelu, F. E., \& Madu, C. O. (2012). Towards empowerment of the Nigerian girl-child, the socio-cultural diagnosis. Journal of Educational and Social Research, 2 (3), 29-34. doi:10.5901/jesr.2012.v2n3p29.

UNICEF (2005). 2005 and Beyond: Accelerating Girls' Education in South Asia. In: Arai, K., \& Tabata, Y. (2006). Socio-cultural factors affecting girls' limited access to school education in North West Frontier Province of Pakistan. November APERA Conference, Hong Kong (28-30). Retrieved on October, 16 from http://edisdat.ied.edu.hk/pubarch/b15907314/full_paper/1394178079.pdf

World Bank (1995). Socioeconomic and Sociocultural factors influencing female participation in Education. Gale, Cengage Learning, September 1 Report. 
Benjamin C. KIPKULEI, Micah C. CHEPCHIENG, Mary J. CHEPCHIENG, Lydia M. BOITT. Selected Factors Affecting Girls' Participation in Primary School Education in Kenya

PROBLEMS

OF EDUCATION

IN THE $21^{\text {st }}$ CENTURY

Volume 48, 2012

61

Advised by Agnaldo Arroio, University of Sao Paulo, Brazil

Received: September 30, 2012

Accepted: November 19, 2012

\begin{tabular}{|ll|}
\hline Benjamin C. Kipkulei & $\begin{array}{l}\text { M.Ed, Programme Manager, Baringo District Center for Early Childhood } \\
\text { Education, P. O. Box 6, Kabarnet, Kenya. } \\
\text { E-mail: kipkuleibenjamin@yahoo.com }\end{array}$ \\
\hline Micah C. Chepchieng & $\begin{array}{l}\text { PhD, Senior Lecturer, Department of Psychology, Counselling and Educa- } \\
\text { tional Foundations, Egerton University, P. O Box 536, Egerton, Kenya. } \\
\text { E-mail: mchemobo@yahoo.com }\end{array}$ \\
\hline Mary J. Chepchieng & $\begin{array}{l}\text { M.A., Assistant Lecturer, School of Education and Theology, Kabarak Uni- } \\
\text { versity, Private Bag, Kabarak, Kenya. } \\
\text { E-mail: mary.chemobo@yahoo.com }\end{array}$ \\
\hline Lydia M. Boitt & $\begin{array}{l}\text { M.Ed., Assistant Lecturer, Department of Psychology, Counselling and Edu- } \\
\text { cational Foundations, Egerton University, P. O Box 536, Egerton, Kenya. } \\
\text { E-mail: Iydiamonny@yahoo.com }\end{array}$
\end{tabular}

